\title{
SCIENTOMETRICS ANALYSIS ON THE USE OF MOLECULAR MARKERS IN STUDIES OF THE SCIAENIDAE FAMILY (TELEOSTEI: PERCIFORMES)
}

\author{
ANÁLISE CIENCIOMÉTRICA DA UTILIZAÇÃO DE MARCADORES \\ MOLECULARES EM ESTUDOS DA FAMÍLIA SCIAENIDAE (TELEOSTEI: \\ PERCIFORMES)
}

\author{
Nathalia Alves DIAMANTE ${ }^{* *}$, Alberto José PRIOLI ${ }^{2}$, Sônia Maria Alves PINTO \\ PRIOLI $^{3}$ \\ $1^{1^{*}}$ Autor para contato: Mestre em Biologia Comparada - Universidade Estadual de \\ Maringá (UEM), Centro de Ciências Biológicas, Departamento de Biologia Celular e \\ Genética. Avenida Colombo, 5790. Zona 07, 87020-900 - Maringá, PR - Brasil. E-mail: \\ nathaliadiamante@gmail.com \\ ${ }^{2}$ Professor Associado da Universidade Estadual de Maringá (UEM), Centro de Ciências \\ Biológicas, Departamento de Biologia Celular e Genética. Avenida Colombo, 5790. Zona \\ 07, 87020-900 - Maringá, PR - Brasil. \\ ${ }^{3}$ Professora Associada da Universidade Estadual de Maringá (UEM), Centro de Ciências \\ Biológicas, Departamento de Biologia Celular e Genética. Avenida Colombo, 5790. Zona \\ 07, 87020-900 - Maringá, PR - Brasil.
}

\begin{abstract}
The Sciaenidae family belongs to the order of the Perciformes with species distributed in The Indian, Atlantic and Pacific Oceans and also in continental inland waters. The phylogenetic and taxonomy relationships of several genres and species are still controversial. Morphological and molecular studies have been undertaken to identify and classify correctly the sciaenid species and estimate their phylogenetic position. Mitochondrial DNA and nuclear DNA markers have been widely used in molecular studies. Since concern in monitoring scientific production is increasing, this study assessed quantitatively research works that employed molecular markers in studies of the Sciaenidae family, through the use of already published papers. The 42 papers analyzed on this study showed that the number of publications has been increasing over the past few years, but still few species have been studied so far. Most of the studies use mitochondrial markers only and aim at estimating the phylogenetic relationships. Results show that Sciaenidae phylogeny is still to be resolved. We suggest further researches with understudied species, especially more comprehensive analysis with molecular data associated with morphological studies.
\end{abstract}

Keywords: Bibliometrics. Mitochondrial DNA. Nuclear DNA. Genes. Sciaenid species.

\section{RESUMO}

Sciaenidae é uma das famílias da ordem Perciformes com espécies distribuídas nos oceanos Índico, Atlântico e Pacifico, e também em águas continentais. As relações filogenéticas e a taxonomia de alguns gêneros e espécies desta família ainda são controversas. Por isso estudos morfológicos e moleculares têm sido realizados para identificar e classificar corretamente espécies de scianídeos e também para estimar sua posição filogenética. Dentro dos estudos moleculares, o DNA mitocondrial vem sendo muito utilizado, assim como os marcadores do DNA nuclear. Como se torna crescente a preocupação com o monitoramento da produção científica, o presente estudo avaliou quantitativamente os trabalhos que utilizam marcadores moleculares em estudos da família Sciaenidae, por meio de um levantamento dos artigos publicados. Foram analisados 42 artigos e verificou-se que o número de publicações aumentou nos últimos 
anos, mas ainda são poucas as espécies estudadas. A maioria dos estudos utiliza apenas marcadores mitocondriais e tem como objetivo estimar as relações filogenéticas. Podese concluir que a filogenia de Sciaenidae ainda não está bem resolvida. Sugere-se novas pesquisas com espécies pouco estudadas, sobretudo análises mais abrangentes com dados moleculares associados com estudos morfológicos.

Palavras-chave: Bibliometria. DNA mitochondrial. DNA nuclear. Genes. Scianídeos.

\section{INTRODUCTION}

Studies on several animal populations through molecular techniques are highly relevant for conservation genetics and have been very useful on both commercially explored population studies and endangered species studies (Frankham et al., 2002).

Sciaenidae, one of the many families of the order Perciformes, is an important worldwide fishing resource, with approximately 70 genres and 270 species found in the Atlantic, Indian and Pacific Oceans (Nelson, 2006). It is numerous and diversified in both sea and in estuary areas of the western part of the South Atlantic, with 45 species and 19 genres (Cervigón, 1993). Among them six genres may be found in continental waters and four (Pachyurus La Cepède, Pachypops Gill, Plagioscion Gill, Petilipinnis Cassati) inhabit the freshwaters of South America (Cassati, 2005).

Morphological (Casatti, 2005) and molecular (Torres, 2006) studies have been realized in order to identify and correctly classify Sciaenid species and also to estimate their phylogenetic position (Jiang et al., 2014; Vergara-Chen et al., 2009). Among molecular analysis methodologies, those based on nuclear or mitochondrial DNA fragments triggered possible genetic and molecular studies involving a great number of individuals.

Mitochondrial DNA has been increasingly employed in the last thirty years to study the evolution of species and populations and has proved to be an efficient tool for molecular ecology and phylogeography (Ballard \& Whitlock, 2004). It has also been employed to evaluate the genetic variability of introduced fish populations (Prioli et al., 2002; Froufe et al., 2002; Gouin et al., 2003; Panarari-Antunes et al., 2012).

Nuclear DNA markers are biparental in origin. They are frequently employed for phylogenetic reconstruction of several taxa and they may be eventually employed to detect hybridization between species (Freeland, 2005).

Researches that make use of molecular markers to study the Sciaenidae family have been surely undertaken, but there is a growing concern on the monitoring of scientific production. In order to perform this assessment, metric, quantitative and qualitative studies are required.

Bibliometrics or Scientometrics is essential for the analysis of scientific production not only for the comprehensiveness of a region but also for a determined scientific area (Macias-Chapula, 1998). Science may be analyzed through its quantitative aspects, generating performance indexes of scientific and technological development that may help in decision-making for the elaboration of a research project (Machado, 2007).

According to Laurindo \& Mafra (2010), Scientometrics does not replace the analytic method on a specific subject but it puts research in the limelight and identifies which areas require more focus. Thus, the objective of this work was to evaluate quantitatively scientific papers that investigated species of the Sciaenidae family making use of molecular markers.

\section{MATERIAL AND METHODS}

This paper comprises a bibliometric analysis of publications involving mitochondrial or nuclear DNA molecular markers in studies on Sciaenidae family species. The collected data indicated the main markers employed and the mostly studied species as well as the development of this area.

Towards this bibliometric development, a research was undertaken based on papers listed on Thomson Reuters Web of Knowledge website, due to the great number of publications and the quality of indexed journals.

The keywords "mitochondrial DNA" and "Sciaenidae" were entered together in data banks as a search strategy, whilst a second search comprised the keywords "nuclear DNA" and "Sciaenidae". 
Repeated publications and papers that did not fit within the required parameters were identified and discharged. In order for the papers to be included in the sample, they should employ some molecular marker of mitochondrial or nuclear DNA to solve taxonomic or phylogenetic issue or any other problem within the Sciaenidae family. Review articles were not included in the samples. Besides the above restrictions, all articles found were taken into consideration regardless of the year of publication.

We read, tabulated and separated the papers according to the year of publication, country in which the study was performed, species analyzed, molecular markers used and objectives. Survey was undertaken between October and December, 2014. Results were provided according to their relative numbers.

\section{RESULTS}

Fifty-five papers with the keywords "mitochondrial DNA" and "Sciaenidae" were found and 11 with the keywords "nuclear DNA nuclear" and "Sciaenidae". Of these, only 42 papers fitted in the research project and served as sample for scientometric analysis.

The papers were published between 1999 and 2014, and most publications occurred in 2009, 2011, 2012 and 2014, with five, seven, nine and five published papers, respectively (Figure 1).

Figure 1: Number of scientific papers published on Sciaenidae, featuring molecular markers of mitochondrial and nuclear DNA, per year.

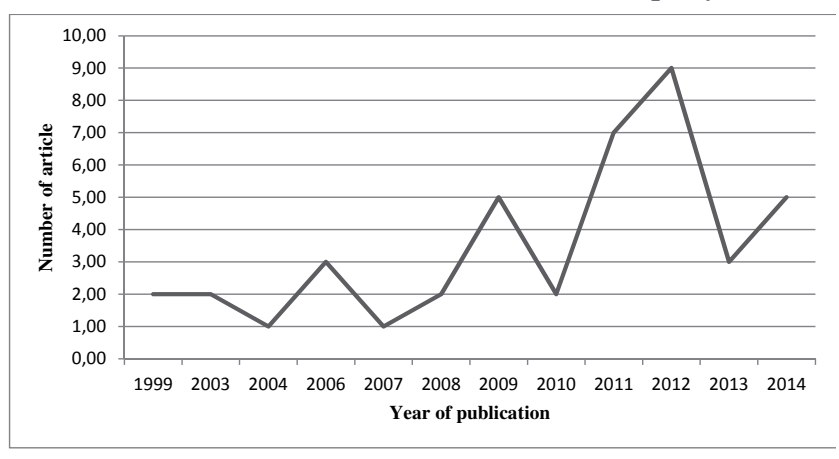

The countries with most publications with the use of molecular markers for studies on the Sciaenidae family were China, with 14 papers $(33.33 \%$ of total publications), Brazil, with nine papers $(21.42 \%)$, The United States, with four papers $(9.5 \%)$ and Japan, with three papers $(7.15 \%)$. France, Argentina, Korea,
Mexico, Uruguay and India published one article each, along with some joint publications such as Spain/ The United States/Panama, Brazil/Germany, Spain/ Panama, Brazil/Australia, Italy/The United States, UK/ South Africa/Angola, with one article each, and 12 publications in total (28.5\%) (Figure 2).

Figure 2: Number of publications on Sciaenidae, featuring molecular markers of mitochondrial and nuclear DNA per country of authors.

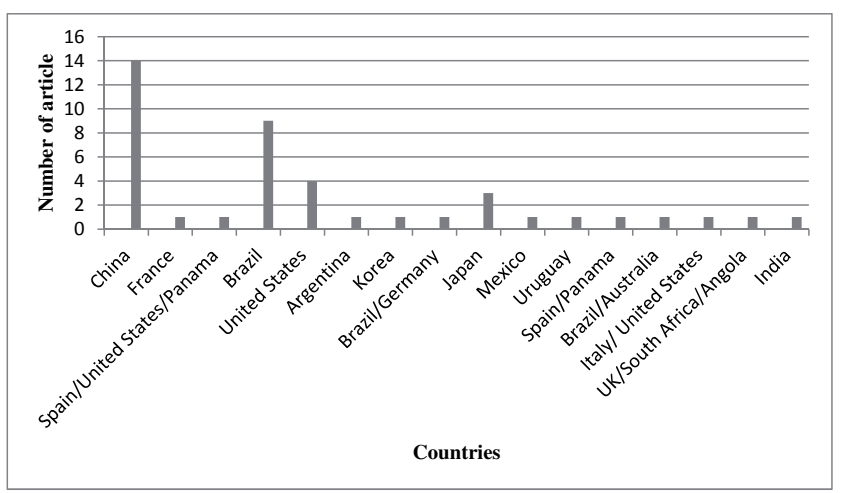

Most research papers dealt with Sciaenidae sea species, which is easily understood as the majority of species of the Sciaenidae family are actually seawater species. In fact, 34 (81\%) out of the 42 selected papers studied only the sea water species; five $(12 \%)$ studied sea and freshwater species and three $(7.15 \%)$ were exclusively based on freshwater species.

24 genres and 102 different species of the Sciaenidae family were studied. Cynoscion, with 20 species, was the most studied genre, throughout 9 articles. The most studied marine species were Larimichthys polyactis (mentioned in 10 papers), Larimichthys crocea (8 papers), Collichthys lucidus (7 papers), Macrodon ancylodon (7 papers), Micropogonias furnieri (7 papers), Miichthys miiuy (6 papers); the freshwater species Plagioscion squamosissimus was studied in 6 papers (Table 1).

In relation to molecular markers, Mitochondrial DNA was used in 32 publications, whereas nuclear DNA markers were employed in 10 . We should mention that several papers used mitochondrial and nuclear DNA markers together (Figure 3). 
Table 1: Number of citations for each Sciaenidae species in selected papers

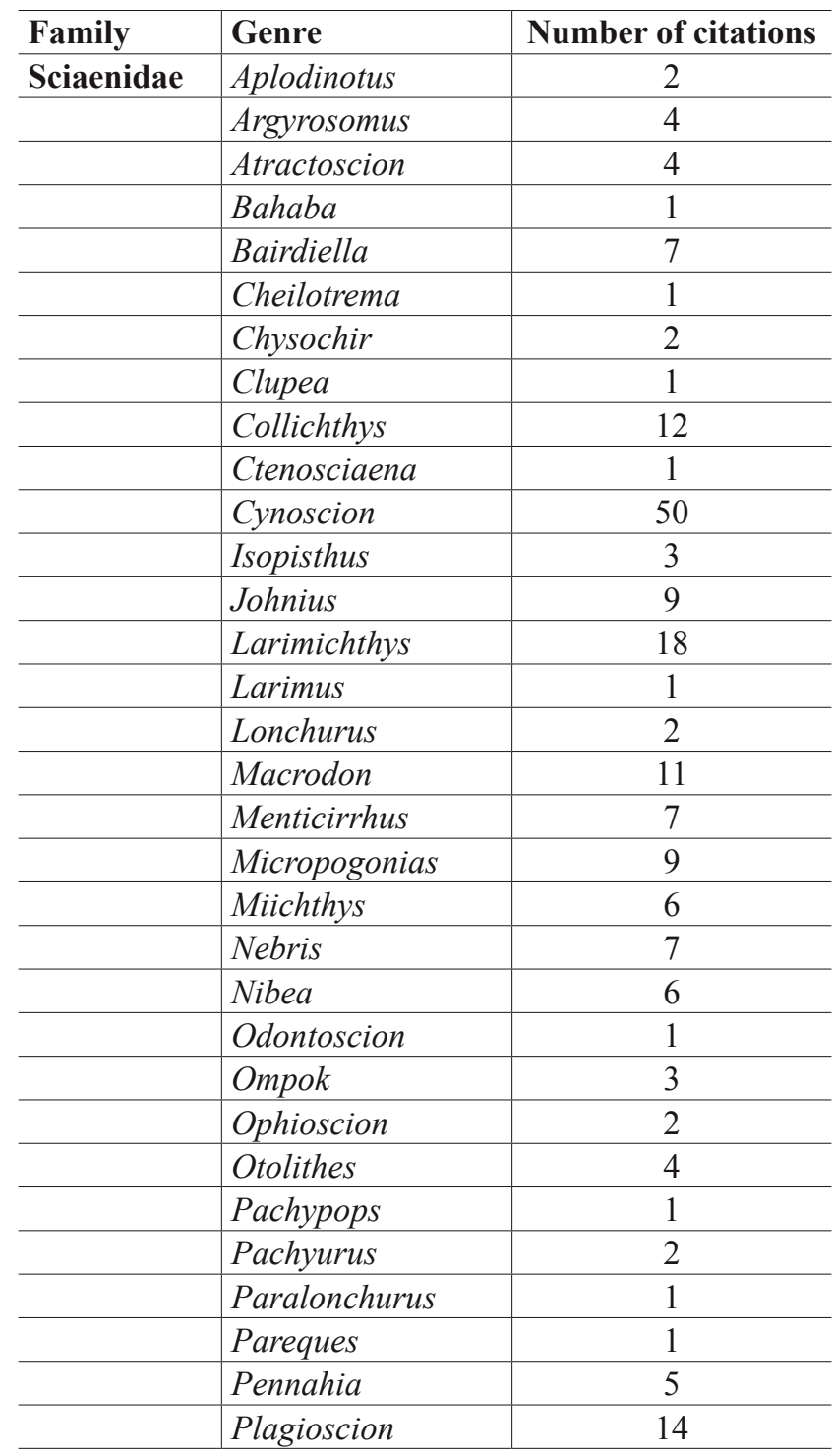

Figure 3: Percentage of molecular marker categories in publications on the Sciaenidae species: Mitochondrial DNA (Mito); Nuclear DNA (Nuclear) and Mitochondrial and Nuclear DNA $(m+n)$

$$
\square \text { Mito Nuclear } \square \mathrm{M}+\mathrm{N}
$$

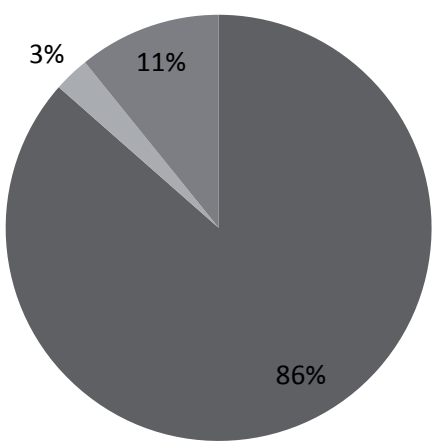

Ten $(23.8 \%)$ out of the 42 papers analyzed, in which sequences of mitochondrial DNA were used, employed specific primers in order to acquire a complete mitochondrial genome. D-loop, the control region of mitochondrial DNA, was the most frequently used, present in 12 papers $(28.6 \%)$, followed by cytochrome genes $(c y t b)$ used in 9 papers $(21.4 \%)$, RNA ribosomal $16 \mathrm{~S}$ ( $r R N A 16 \mathrm{~S})$ used in 7 papers $(16.6 \%)$, cytochrome c oxidase $(C O I)$ in 6 papers $(14.3 \%)$ and gene ATPase $6 / 8$ used in 3 papers $(7.14 \%)$.

Most articles aimed to comprehend the phylogenetic position of the species within the Sciaenidae family or the genetic diversity and structure of the populations under analysis.

Related to the nuclear DNA markers, sequences of RAG 1, Tmo 4C4 and Rhodopsin genes were each analyzed in two (14.28\%) of the investigated papers. The exon-primed intron-crossing (EPIC) marker, a nuclear marker type that provides various advantages in phylogenetic studies (LI et al., 2010) and RNF213, MLL and IRBP genes were each present in one paper $(9.5 \%)$. Table 2 lists the mitochondrial and nuclear DNA markers used on the analyzed works.

The main nuclear DNA techniques that employ nuclear DNA, such as Restriction Fragment Length Polymorphisins (RFLP), Random Amplified Polymorphic DNA (RAPD) and Single Nucleotide Polymorphism (SNPs), were found in the publications analyzed. RFLP was used in 5 papers $(11.90 \%)$, RAPD in $2(4.76 \%)$ and SNP in only one publication.

The analyzed papers mainly focused on the phylogenetic position of the species within the Sciaenidae family or the genetic diversity and structure of populations. Taxonomy, phylogeography, hybridization events and genetic mapping were also research objectives of some studies (Figure 4).

Figure 4: Number of papers and their objectives in the analysis on the Sciaenidae family.

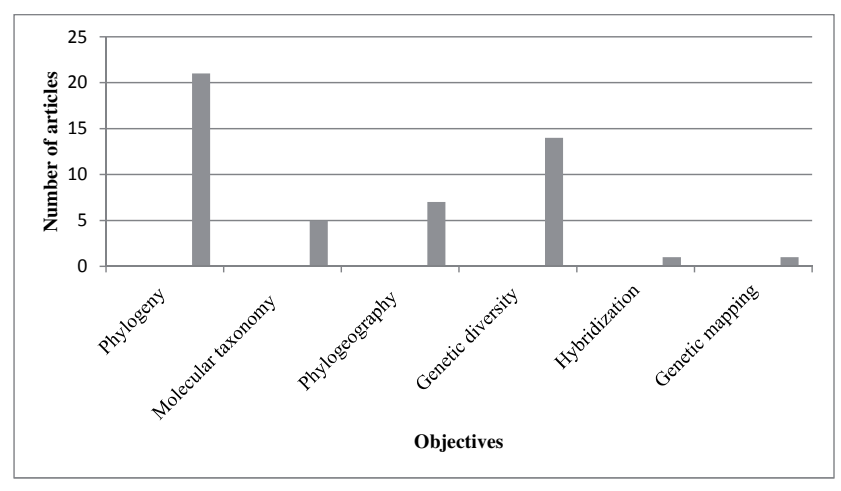


Both nuclear and mitochondrial markers proved to be effective in solving taxonomy and phylogenetic issues and evaluating the genetic variability within the Sciaenidae family. However, mitochondrial markers were the most employed among the papers, despite a larger variety of nuclear markers being used (Table 2).

Table 2: Markers of the nuclear and mitochondrial genome used in papers on Sciaenidae family.

\begin{tabular}{l|l}
\hline \multicolumn{2}{c}{ Molecular markers } \\
\hline \multicolumn{1}{c}{ Mitochondrial } & \multicolumn{1}{c}{ Nuclear } \\
\hline $\begin{array}{l}\text { Complete mitochondrial } \\
\text { genome }\end{array}$ & $\begin{array}{l}\text { Exon- primed intron- crossing } \\
\text { (EPIC) }\end{array}$ \\
\hline $\begin{array}{l}\text { Cytochrome C oxidase } \\
\text { (COI) }\end{array}$ & RNF213 \\
\hline Cytochrome B $(C y t b)$ & MLL \\
\hline ATPase subunit 6/8 & IRBP \\
\hline Ribosomal 16S RNA & Tmo4c4 \\
\hline & RAG 1 \\
RFLP \\
RAPD \\
SNPo region (D-loop)
\end{tabular}

\section{DISCUSSION}

There has been an increase in the publications that use molecular markers in recent years. Fabrin et al. (2014), in their scientometric analysis of markers used in cyclid phylogeny, also reported an increase in publications that have employed molecular markers in the last years.

Similarly, we attribute this increase to the decrease in costs of molecular techniques, the necessary equipment that became more accessible, the researchers training and the dissemination and availability of new gene sequences in on-line data banks, making the research work easier. Furthermore, sharp falls in the number of publications between one year and another may be due to production cycles of research teams, as there is an increase of publications in the following year.

Regarding the affiliation of research groups that studied species of the Sciaenidae family through the use of molecular markers, most are from China, followed by Brazil. Sciaenidae species are found in The Atlantic, Indian and Pacific Oceans (Nelson, 2006). This explains the highest number of papers by research teams in China, which has its coast embraced by The Pacific Ocean, and Brazil by The Atlantic. This also explains the lack of research on Sciaenidae species of The Indian Ocean.

Most Sciaenidae species studied in these papers are marine species, Plagioscion squamosissimus was the mostly studied freshwater species through mitochondrial or nuclear DNA molecular markers. This shows its ecological and economic importance, even though six papers on this species are still of little significance. In spite of species diversity, few investigations dealt with the phylogenetic relationships of the Sciaenidae and the available studies do not provide satisfactory results (Santos et al., 2013).

The most commonly used molecular markers were mitochondrial. Mitochondrial DNA is one of the most used in genetic evolutionary studies, population, phylogeography and phylogenetic analysis (Brown, 2008).

The most frequently used mitochondrial DNA D-loop has been the main molecular marker to analyze genetic variation, including fish species (PanarariAntunes et al., 2008; Hirayama et al., 2010; Lo Presti et al., 2010).

The control region of the mitochondrial DNA characterized by the displacement loop (D-loop) is responsible for the control of light and heavy replication strands of mitochondrial DNA. As it is the only non-codified region of the mitochondrial genome, it suffers the lowest selection pressure from the rest of the molecule, resulting in high mutation rates. The control region evolution rate is two to five times greater than the rate of encoded mitochondrial proteins (Meyer, 1994; Avise, 2004). Great variability in the region has made it extremely efficient in detecting differentiation and assessing the genetic and phylogeographic variability in fish (Avise, 2009; Brown, 2008). As well as the Cytochrome b (Cyt b) gene that codifies an enzyme of the respiratory chain of the mitochondria oxidation metabolism (Kocher \& Stepien, 1997) and is extensively used as "molecular clock" to calculate the genetic differentiation between species (García et al., 2000; Avise, 2004; Chen et al, 2014). However, it is not suitable to estimate differences of intraspecies populations (Nei \& Kumar, 2000).

The ribosomal RNA genes have been much studied in plants and animals, especially for genetic characterization of species, evolution relationship and gene expression (Martins \& Wasko, 2004). The 16S rRNA provides useful information for phylogenetic 
inferences, that is why it was greatly employed in papers related to the phylogeny of the Sciaenidae family; similarly to the ATPase 6/8 gene that is widely used for phylogenic analysis and phylogeography of several fish species (Chow \& Ushiama, 2004; Hurwood et al., 2008; Dammannagoda et al., 2008; Vergara-Chen et al., 2009).

The mitochondrial gene cytochrome c oxidase (COI) was selected for the development of a data bank of DNA barcoding to identify species and amplify the discovery index of new species (Moritz \& Cicero, 2004). COI is very efficient in discriminating species and provides a highly preserved sequence that makes the use of universal primers easier (Hebert et al., 2003). Thus, it has been greatly employed in taxonomy-aimed papers.

Among the nuclear markers, the Tmo-4C4 nuclear genes, RAG 1 and rhodopsin, RNF213, MLL and IRBP were used. The phylogenetic relationships between Stellifer, Odontoscion, Ophioscion and Bairdiella (Sciaenidae, Perciformes) were assessed through nuclear genes Tmo-4C4, RAG 1 and rhodopsin (Barbosa et al., 2014). The nuclear marker Tmo$4 \mathrm{C} 4$ has been highly used in genre and fish family phylogenetic analysis (Rüber et al., 2004; Rocha et al., 2008) and it showed to be effective for molecular taxonomy combined with mitochondrial markers (Musilová et al., 2009; Viñas et al., 2010).

The nuclear gene RAG 1 has been employed in phylogeny and phylogeography research (Barbosa et al., 2014; Cooke et al., 2012), whereas a new nuclear marker, RNF213, and genes Rhodopsin, MLL and IRBP were used for the phylogenetic analysis among several Sciaenidae species (Li et al., 2009).

Most analyzed papers mainly focused on understanding the phylogenetic position of the species within the Sciaenidae family or the genetic diversity and structure of the studied populations. Taxonomy, phylogeography, hybridization events and genetic mapping were the aim of some of the researches. Due to that, they employed effective markers to answer to these questions, such as the D-loop, which is effective to detect differentiation and evaluate genetic variability and phylogeography in fish; ATPase, widely used to analyze phylogeny and phylogeography; COI, efficient to discriminate species; Tmo-4C4, effective for molecular taxonomy when used combined with mitochondrial markers, among others.

\section{CONCLUSION}

The number of papers that use molecular markers in studies on the Sciaenidae family was low, considering its diversification and population. In addition, some phylogenetic relationships among some genres and species have not been entirely accounted for. Although there has been an increase in publications over the past years, they are mostly research works of scientists in four countries (China, Brazil, The United States and Japan), which have actually studied the species found in their geographic region while other species from other regions were left aside.

Less than half of the known Sciaenidae species have been studied through mitochondrial and nuclear DNA sequences. Most of the analyzed papers dealt with mitochondrial DNA sequences only, even though the combined analysis of mitochondrial and nuclear DNA sequences are much more productive.

Thus, we suggest that further research should be performed to improve knowledge on the phylogeny, phylogeography and taxonomy and also to assess the genetic diversity within the Sciaenidae family, especially through more comprehensive analyses and among the understudied groups.

\section{REFERENCES}

AVISE, J. C. Phylogeography: retrospect and prospect. Journal of Biogeography, v. 36, p. 315, 2009.

AVISE, J. C. Molecular Markers, Natural History, and Evolution. Sinauer Associates, 2004. 684 p.

BALLARD, W. O.; WHITLOCK, M. C.; The incomplete natural history of mitochondria. Molecular Ecology, v. 13, p. 729-744, 2004.

BARBOSA, A. J. B et al. Molecular Phylogeny of Weakfish Species of the Stellifer Group (Sciaenidae, Perciformes) of the Western South Atlantic based on Mitochondrial and Nuclear Data. PLoS ONE, v. 9, n. 7, 2014.

BROWN, K. H. Fish mitochondrial genomics: sequence, inheritance, and functional variation. Journal of fish biology, v. 72, p. 355-374, 2008.

CASATTI, L. Revision of the South American freshwater genus Plagioscion (Teleostei, Perciformes, Sciaenidae). Revista Zootaxa, v. 1080, p. 39-64, 2005.

CERVIGÓN, F. Los peces marinos de Venezuela. Caracas: Fundación Científica Los Roques, 1993.

CHEN, S. et al. Differentiation of fish species in Taiwan Strait by PCR-RFLP and lab-on-a-chip system. Food Control, v. 44, p. 26-34, 2014. 
CHOW, S.; USHIAMA, H. Global population structure of albacore Thunnus alalunga inferred by RFLP analysis of the mitochondrial ATPase gene. Marine Biology, v. 123, n. 1, p. 39-45, 2004.

COOKE, G. M.; CHAO, N. L.; BEHEREGARAY, L. B. Marine incursions, cryptic species and ecological diversification in Amazonia: the biogeographic history of the croaker genus Plagioscion (Sciaenidae). Journal of Biogeography, v. 39, p. 724-738, 2012.

DAMMANNAGODA, S. T.; HURWOOD, D. A.; MATHER, P. B. Evidence for fine geographical scale heterogeneity in gene frequencies in yellowfin tuna Thunnus albacares from the north Indian Ocean around Sri Lanka. Fisheries Research, v. 90, p. 147-157, 2008.

FABRIN, T. M. C. et al. A utilização de marcadores na filogenia dos ciclídeos (Teleostei: Perciformes): uma análise cienciométrica. Enciclopédia Biosfera, Centro Científico Conhecer - Goiânia, v. 10, n. 18, p. 3118-3123, 2014.

FRANKHAM， R.; BALLOU，J.R.; BRISCOE， D.A. Introduction to conservation Genetics. Cambridge: Camdridge University Press, 2002.

FREELAND, J. R. Molecular Ecology. Chichester: John Wiley \& Sons, 2005.

FROUFE, E. et al. mtDNA sequence supports an Asian ancestry and single introduction of the common carp into the Danubian basin. Journal of fish Biology, v. 61, n. 1, p. 301-304, 2002.

GARCÍA, G.; WLASIUK, G.; LESSA, E. P. High levels of mitochondrial cytochrome $b$ divergence in annual killifishes of the genus Cynolebias (Cyprinodontiformes, Rivulidae). Zoological Journal of the Linnean Society, v. 129, p. 93$110,2000$.

GOUIN, N. et al. Origin and colonization history of the White-clawed crayfish, Austropotamobius pallipes in Ireland. Heredity, v. 91, n. 1, p. 70-77, 2003.

HEBERT, P. D. N. et al. Biological identifications through DNA barcodes. Proceedings of the Royal Society of London, v. 270, p. 313-321, 2003.

HIRAYAMA, M. et al. Intraspecific variation in the mitochondrial genome among local populations of Medaka Oryzias latipes. Gene, v. 457, p. 13-24, 2010.

HURWOOD, D. A.; ADAMSON, E. A. S.; MATHER, P. B. Evidence for strong genetic structure in a regionally important, highly vagile cyprinid Hemicorhynchus lobatus in the Mekong river. Ecology of Freshwater Fish, v. 17, p. 273-283, 2008.

JIANG, L. et al. Phylogenetic estimation of Sciaenidae in the East China Sea inferred from nuclear EPIC DNA sequence variation. Biochemical Systematics and Ecology, v. 53, p. 69-75, 2014.
KOCHER, T. D.; STEPIEN, C. A. Molecular systematics of fishes. San Diego: Academic Press, 1997. 311 p.

LAURINDO, R.; MAFRA, T. Cienciometria da revista Comunicação \& Sociedade identifica interfaces da área. Comunicação \& Sociedade, n. 53, p. 233-260, 2010.

LI, B. et al. RNF213, a new nuclear marker for acanthomorph phylogeny. Molecular Phylogenetics and Evolution, v. 50, p. 345-363, 2009.

LI, C.H.; RIETHOVEN, J. M.; MA, L.B. Exon-primed intron-crossing (EPIC) markers for non-model teleost fishes. BMC Evolution Biology, v. 10, p. 1471-2148, 2010.

LO PRESTI, R. et al. PCR-RFLP analysis of mitochondrial DNA in tench Tinca tinca. Journal of Fish Biology, v. 76, p. 401-407, 2010.

MACHADO, R. N. Análise cientométrica dos estudos bibliométricos publicados em periódicos da área de biblioteconomia e ciência da informação $(1990$ - 2005). Perspectivas em Ciência da Informação, v. 12, n. 3, p. 2-20, 2007.

MACIAS-CHAPULA, C. A. O papel da informetria e cienciometria e sua perspectiva nacional e internacional. Ciência da Informação, v. 27, n. 2, p. 134-140, 1998.

MARTINS, C.; WASKO, A. P. Organization and evolution of $5 \mathrm{~S}$ ribosomal DNA in the fish genome. In: WILLIAMS, C. R. Focus on Genome Research. Nova York: Nova Science Publishers, 2004. p. 335-363.

MEYER, A. DNA technology and phylogeny of fish In: BEAUMONT, A.R. (Ed). Genetics and Evolution of Aquatic Organisms. London: Chapman e Hall, 1994. p. 219-249.

MORITZ, C.; CICERO, C. DNA barcoding: Promises and pitfalls. PLoS Biology, v.2 , p. 1529-1534, 2004.

MUSILOVÁ, Z.; SCHINDLER, I.; STAECK, W. Description of Andinocara stalsbergi sp.n. (Teleostei: Cichlidae: Cichlasomatini) from Pacific coastal rivers in Peru, and annotations on the phylogeny of the genus. Vertebrate Zoology, v. 59, n. 2, p. 131-141, 2009.

NEI, M.; KUMAR, S. Molecular Evolution and Phylogenetics. Oxford: Oxford University Press, 2000.

NELSON, J.S. Fishes of the World. New York: John Wiley and Sons, 2006.

PANARARI-ANTUNES et al. Genetic divergence among invasive and native populations of Plagioscion squamosissimus (Perciformes, Sciaenidae) in Neotropical regions. Journal of Fish Biology. v. 80, p. 2434-2447, 2012

PANARARI-ANTUNES, R. S. et al. Molecular variability in Brycon cf. pesu Muller and Troschel, 1845 (Characiformes:Characidae) from the Araguaia-Tocantins basin. Genetics and Molecular Research v. 7, p. 95-106, 2008. 
PRIOLI, S. M. A. P. et al. Identification of Astyanax altiparanae (Teleostei, Characidae) in the Iguaçu river, Brazil, based on mitochondrial DNA and RAPD markers. Genetics and Molecular Biology, v. 25, p. 421-430, 2002

ROCHA, L. et al. Historical biogeography and speciation in the reef fish genus Haemulon (Teleostei: Haemulidae). Molecular Phylogenetics and Evolution, v. 48, p. 918928, 2008.

RÜBER, L. et al. Evolutionary and biogeographic patterns of the Badidae (Teleostei: Perciformes) inferred from mitochondrial and nuclear DNA sequence data. Molecular Phylogenetics and Evolution, v. 32, p. 1010-1022, 2004.

SANTOS, S. et al. Molecular phylogeny of the western South Atlantic Sciaenidae based on mitochondrial and nuclear data. Molecular Phylogenetics and Evolution, v. 66, p. 423-428, 2013.

TORRES, R. A. Molecular taxonomy of Plagioscion Heckel (Perciformes, Sciaenidae) and evidence from mtDNA RFLP markers for an invasive species in the Paraná river, Southern Brazil. Revista Brasileira de Zoologia v. 23, p. 1235-1242, 2006.

VERGARA-CHEN, C. et al. A mitochondrial DNA based phylogeny of weakfish species of the Cynoscion group (Pisces: Sciaenidae). Molecular Phylogenetics and Evolution, v. 53, p. 602-607, 2009.

VIÑAS, J.; ALVARADO, B.; PLA, C. Phylogeography and phylogeny of the epineritic cosmopolitan bonitos of the genus Sarda (Courvier): inferred patterns of intraand inter-oceanic connectivity derived from nuclear and mitochondrial DNA data. Journal of Biogeography, v. 37, p. 557-570, 2010.

YAN, J. et al. Maternal inheritance in polyploid fish inferred from mitochondrial ATPase genes analysis. Progress in Natural Science, v. 19, p. 693-698, 2009. 